\title{
LONG-TERM STORAGE OF OIL PALM GERMPLASM ZYGOTIC EMBRYO USING CRYOPRESERVATION
}

\author{
NORZIHA, A*; MARHALIL, M*; FADILA, A M*; ZULKIFLI, $Y^{*}$; MAIZURA, I*; MOHD DIN, A*; \\ RAJANAIDU, $\mathbf{N}^{\star}$ and KUSHAIRI, $\mathbf{A}^{*}$
}

\begin{abstract}
The MPOB germplasm collections from various parts of the world were planted mainly at MPOB Research Station, Kluang, Johor, Malaysia. The collections were maintained in the form of field gene bank. Conserving the genetic materials in ex-situ living collections requires high cost of maintenance, large land area and the palms are exposed to diseases and extreme weather conditions. Experiments were conducted to study the possibility of preserving oil palm tissues for long-term storage at ultra-low temperature $\left(-196^{\circ} \mathrm{C}\right)$ in liquid nitrogen. This technique, known as cryopreservation requires lower cost of maintenance, lesser space and protects the genetic materials from pests and diseases. Oil palm seeds are intermediate between orthodox and recalcitrant. Oil palm seeds that have high levels of moisture lose viability when stored in liquid nitrogen. Experiments were conducted to study the possibility of cryopreserving smaller tissues such as oil palm zygotic embryos. Simple desiccation methods were applied to reduce the moisture levels of the embryos namely room temperature, laminar flow and silica gel. These methods were shown to be useful for zygotic embryos. Silica gel, however, is advantageous as it removes the moisture in relatively shorter period than the other two methods. The same approach has potential to be applied to cryopreserve oil palm pollen.
\end{abstract}

\section{Keywords: cryopreservation, oil palm.}

Date received: 13 May 2017; Sent for revision: 6 June 2017; Received in final form: 11 August 2017; Accepted: 7 September 2017.

\section{INTRODUCTION}

MPOB has the largest oil palm germplasm collection in the world (Rajanaidu, 1994; Rajanaidu and Jalani, 1994). The germplasm collections are being conserved in ex situ field genebank. However, these plots require high maintenance cost and large amount of land. Apart from being exposed to diseases and extreme climate conditions, the materials need to be regenerated every 25 years (Williams and Hsu, 1970). Therefore, new technique

Malaysian Palm Oil Board,

6 Persiaran Institusi, Bandar Baru Bangi,

43000 Kajang, Selangor, Malaysia.

E-mail: norziha.abdullah@mpob.gov.my for oil palm germplasm conservation was explored to preserve a part of the germplasm in the form of cryopreservation.

There are three types of seed storage behaviour; orthodox, intermediate and recalcitrant seeds. Orthodox seeds can be dried without damage at low moisture contents while recalcitrant seeds do not survive drying to any large degree and are thus not amenable to longterm storage (Hong et al., 1998). Oil palm seeds show intermediate seed storage behaviour. Intermediate seeds can be desiccated to around 10\%-12\% moisture content and can tolerate freezing temperatures (Ellis et al., 1991).

Cryopreservation refers to the non-lethal storage of biological tissues at ultra-low temperature, 
usually that of liquid nitrogen $\left(-196^{\circ} \mathrm{C}\right)$. At low temperatures, biological and biochemical activities in the cells are stopped. Therefore, theoretically, tissues can be stored for unlimited period of time. It causes no change in viability, vigour and genetic make-up of the cryopreserved materials (Mandal et al., 2000).

Cryopreservation technique offers minimum space and low maintenance and has turn out to be very essential tool for long-term storage of germplasm materials. It appears to be the most practicable method for storing recalcitrant seeds and species that are vegetatively propagated. Cryopreservation using a desiccation procedure is the simplest technique as it involves dehydrating the plant material to a suitable moisture content followed by rapid freezing through direct immersion in liquid nitrogen. Desiccation has been utilised mainly with zygotic and somatic embryos (Grout et al., 1983; Chaudhury et al., 1991). Panis et al. (2001) reported that desiccation using a closed vial containing silica gel is more reproducible.

Embryo is preferred as the first tissue for oil palm cryopreservation because of its relatively smaller in size as compared to seeds and kernels. Bigger tissues are more constrained by desiccation and freezing sensitivity. Several publications on recalcitrant and intermediate species (e.g. oil palm, cocoa, rubber) reported that excised embryos are relatively more tolerant to dessication and cryoexposure than whole seeds (Bajaj, 1984; Radhamani and Chandel, 1992; Normah et al., 1994; Makeen et al., 2005).

For successful cryopreservation, many elements such as status of source-plant, materials, personnel, culture conditions, pre-treatment conditions, cryopreservation techniques, cryogenic facilities, organisations and post-thawing are involved (Reinhoud et al., 2000; Reed et al., 2004). At MPOB, some five-year cryopreserved embryos have been germinated on MS basal media. The success rate was $70 \%$. Similar results were obtained in citrus at the National Bureau of Plant Genetic Resources (NBPGR) in India where after an average of 6.3 to 8.4 years of cryo-storage, between $69 \%$ and $81 \%$ of accessions per species retained more than $70 \%$ of the viability after desiccation (Malik et al., 2012). In some germplasm conservation centres, 20\% recovery is sufficient for long-term preservation (Golmirzaie and Panta, 2000). Reed (2001) reported that many authors consider that survival should be higher than $40 \%$. It is crucial that those percentages be reproducible. In this study, experiments were conducted to examine the possibility of cryopreserving smaller tissues such as oil palm zygotic embryos. Simple desiccation methods were applied to reduce the moisture levels of the embryos namely room temperature, laminar flow and silica gel.

\section{MATERIALS AND METHODS}

\section{Plant Materials}

Experiments were carried out on oil palm from various MPOB germplasm collections planted at MPOB Research Station Kluang, Johor, Malaysia. Embryos were excised from oil palm fruits collected at random from five germplasm collections namely Angola, Cameroon, Ghana, Senegal and Guinea. Fruits from a standard cross (DxP) were used as the control. For each germplasm, one dura and one tenera open-pollinated bunch was collected at random.

\section{Preparation of the Seeds}

The harvested bunches were labelled and the mesocarp manually removed from the fruit. The clean seeds were then cracked and the kernels obtained were surface-sterilised for $20 \mathrm{~min}$ using $0.05 \%$ Tween 20 and $0.01 \%$ mercuric chloride, followed by three times rinsing with sterile water.

\section{Methods to Reduce Moisture Content}

Desiccation of seeds, kernels and embryos was carried out using room temperature, air laminar flow and silica gel, respectively.

\section{Room Temperature}

The seeds were subjected to controlled room temperature with an average of $25^{\circ} \mathrm{C}$ and $\mathrm{RH}$ of $70 \%$. The moisture content of the excised embryos was measured at 10, 20 and 30 days after treatment.

\section{Air Laminar Flow}

The kernels obtained from the seeds were kept in air laminar flow and the moisture contents of the excised embryos were measured after 30, 60 and 90 days.

\section{Silica Gel}

The embryos excised from fresh kernels were exposed to $15 \mathrm{~g}$ silica gel in sealed Petri dishes. The moisture content of the excised embryos was measured at $0,1,2,3,4$ and $5 \mathrm{hr}$ of desiccation. Embryos at $0 \mathrm{hr}$ of exposure are considered untreated and used as control. For every hour, some embryos were cryopreserved and germinated in MS basal medium to monitor the viability rate.

For each experiment, three replicates (five embryos/replicates) were used. The moisture contents of all treated embryos were measured using oven method described by the International Seed Testing Association, ISTA (1985). Moisture 
content is expressed by the difference between fresh and dry weight of the samples. Dry weight was obtained after drying of embryos at $105^{\circ} \mathrm{C}$ for $16 \mathrm{hr}$. The moisture content is then calculated using the following formula:

$$
\begin{aligned}
& \text { Percentage of moisture content }=\frac{\mathrm{M} 2-\mathrm{M} 3}{\mathrm{M} 2-\mathrm{M} 1} \times 100 \% \\
& \text { where, } \\
& \text { M1 is aluminium foil weight; } \\
& \text { M2 is aluminium foil weight + sample fresh weight; } \\
& \text { and } \\
& \text { M3 is aluminium foil weight + sample dry weight. }
\end{aligned}
$$

Dehydrated embryos for all treatments using silica gel method were sealed in propylene cryovials and directly immersed in liquid nitrogen $\left(-196^{\circ} \mathrm{C}\right)$. After $16 \mathrm{hr}$ (at least), the embryos were thawed in $40^{\circ} \mathrm{C}$ water bath for $1 \mathrm{~min}$. Embryos were then transferred onto MS basal medium to determine rate of germination. The embryos were incubated at a temperature of $24^{\circ} \mathrm{C}-25^{\circ} \mathrm{C}$ under $16 / 8$ (light/ dark) photoperiod.

\section{RESULTS AND DISCUSSION}

\section{Room Temperature Method}

The initial mean moisture contents of the embryos excised from the fresh kernels were approximately $36.4 \%$ ranging from $31.5 \%$ to $40.0 \%$ (Table 1). After 10 days of exposure at room temperature, the mean moisture contents decreased to $20.8 \%$ ranging from $11.3 \%$ to $33.2 \%$. Mean moisture contents of $12.4 \%$ and $10.4 \%$ were obtained after 20 days and 30 days of exposure in room temperature, respectively.

\section{Air Laminar Flow Method}

The initial mean moisture content for air laminar flow method was $37.6 \%$. After 30 days, the mean moisture content of embryos excised from kernels was reduced to $17.6 \%$ whereas, embryos from DxP progenies was decreased from $41.8 \%$ to $9.9 \%$, respectively (Table 2). However, after 90 days the moisture content of embryos has not stabilised and the data was not useful and should be discarded. Experiment conducted at 90 days where drying beyond critical moisture may impose a desiccation stress which led to solute effect such as $\mathrm{pH}$ changes, increasing electrolyte concentrations, protein denaturation, membrane phase transition and macromolecular interaction and then damage of the cell (Dumet and Benson, 2000). It is suggested that 30 days is sufficient to obtain moisture content of $10 \%-20 \%$ for air laminar flow method.

\section{Silica Gel Method}

The moisture contents of embryos at different hour of dehydration are shown in Table 3. The initial mean moisture content was $37.1 \%$. The moisture content decreased to $28.3 \%$ after $1 \mathrm{hr}$ and gradually dropped to $22.9 \%, 17.5 \%, 13.0 \%$ and $8.8 \%$ for subsequent hours of desiccation. Embryos with no treatment showed the lowest viability and survival when cultured in vitro. Only $16.7 \%$ of survival rate was obtained for the fresh embryos extracted from kernels (Table 4). However, with increasing duration of desiccation (1 - 5 hr), there was an increase in viability up to $74.7 \%$ at $4 \mathrm{hr}$. After $4 \mathrm{hr}$ in the silica gel, the germination rate of cryopreserved embryos ranged from $53.3 \%$ to $93.3 \%$. A similar result was obtained in oil palm, survival of cryopreserved

TABLE 1. MOISTURE CONTENT FOR OIL PALM EMBRYOS DEHYDRATED USING ROOM TEMPERATURE

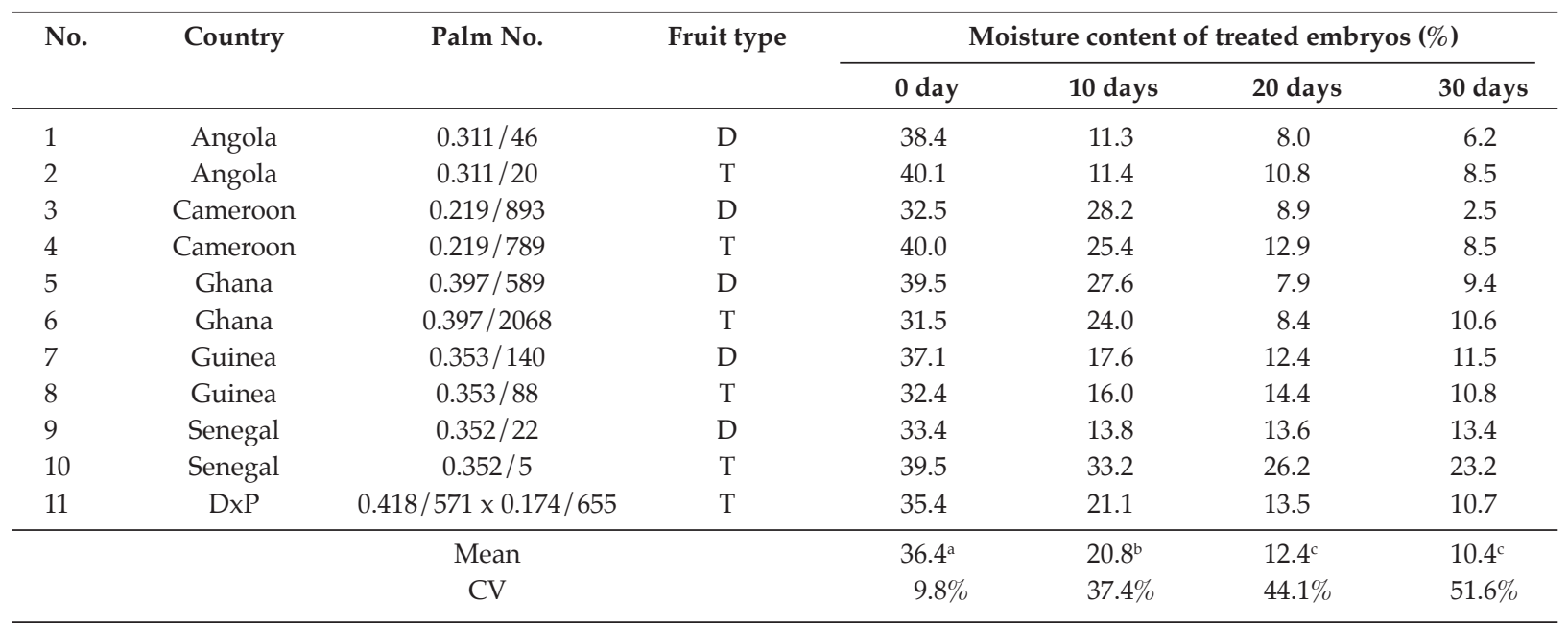

Note: D - Dura, T - Tenera, P - Pisifera. Means within the same column with the same letter are not significantly different at P $\leq 0.05$ from Tukey's Studentised Range (MSD) test. Figures in the row are minimum and maximum values. CV - coefficient of variations. 


\begin{tabular}{|c|c|c|c|c|c|c|c|}
\hline \multirow[t]{2}{*}{ No. } & \multirow[t]{2}{*}{ Country } & \multirow[t]{2}{*}{ Palm No. } & \multirow[t]{2}{*}{ Fruit type } & \multicolumn{4}{|c|}{ Moisture content of treated embryos (\%) } \\
\hline & & & & 0 day & 30 days & 60 days & 90 days \\
\hline 1 & Angola & $0.311 / 46$ & $\mathrm{D}$ & 42.8 & 29.5 & 7.0 & 14.1 \\
\hline 2 & Angola & $0.311 / 20$ & $\mathrm{~T}$ & 40.6 & 34.6 & 12.9 & 6.4 \\
\hline 3 & Cameroon & $0.219 / 893$ & $\mathrm{D}$ & 35.1 & 21.0 & 14.2 & 7.8 \\
\hline 4 & Cameroon & $0.219 / 789$ & $\mathrm{~T}$ & 30.6 & 15.6 & 12.4 & 12.3 \\
\hline 5 & Ghana & $0.397 / 589$ & $\mathrm{D}$ & 50.8 & 9.9 & 2.6 & 6.8 \\
\hline 6 & Ghana & $0.397 / 2068$ & $\mathrm{~T}$ & 41.0 & 11.1 & 5.3 & 4.2 \\
\hline 7 & Guinea & $0.353 / 140$ & $\mathrm{D}$ & 36.3 & 11.1 & 7.4 & 6.6 \\
\hline 8 & Guinea & $0.353 / 88$ & $\mathrm{~T}$ & 28.8 & 9.8 & 5.4 & 15.8 \\
\hline 9 & Senegal & $0.352 / 22$ & $\mathrm{D}$ & 33.1 & 8.9 & 6.9 & 12.8 \\
\hline 10 & Senegal & $0.352 / 5$ & $\mathrm{~T}$ & 37.4 & 24.3 & 10.7 & 13.1 \\
\hline \multirow[t]{3}{*}{11} & DxP & $0.418 / 571 \times 0.174 / 655$ & $\mathrm{~T}$ & 41.8 & 9.9 & 6.3 & 18.3 \\
\hline & & Mean & & $37.6^{\mathrm{a}}$ & $17.6^{\mathrm{b}}$ & $8.5^{c}$ & $9.9^{c}$ \\
\hline & & $\mathrm{CV}$ & & $17.2 \%$ & $52.7 \%$ & $45.3 \%$ & $40.4 \%$ \\
\hline
\end{tabular}

Note: D - Dura, T - Tenera, P - Pisifera. Means within the same column with the same letter are not significantly different at $\mathrm{P} \leq 0.05$ from Tukey's Studentised Range (MSD) test. Figures in the row are minimum and maximum values. CV - coefficient of variations.

TABLE 3. MOISTURE CONTENT FOR OIL PALM EMBRYOS DEHYDRATED USING SILICA GEL METHOD

\begin{tabular}{|c|c|c|c|c|c|c|c|c|c|}
\hline No. & Country & Palm No. & Fruit type & \multicolumn{6}{|c|}{ Moisture content of treated embryos (\%) } \\
\hline 1 & Angola & $0.311 / 46$ & $\mathrm{D}$ & 36.0 & 27.3 & 23.3 & 19.0 & 13.9 & 9.0 \\
\hline 2 & Angola & $0.311 / 20$ & $\mathrm{~T}$ & 40.9 & 29.9 & 24.6 & 20.6 & 15.8 & 12.0 \\
\hline 3 & Cameroon & $0.219 / 893$ & $\mathrm{D}$ & 33.0 & 24.0 & 22.4 & 18.3 & 15.2 & 2.2 \\
\hline 4 & Cameroon & $0.219 / 789$ & $\mathrm{~T}$ & 34.3 & 23.1 & 17.6 & 15.4 & 14.1 & 11.7 \\
\hline 7 & Guinea & $0.353 / 140$ & $\mathrm{D}$ & 40.3 & 32.6 & 25.1 & 19.9 & 15.0 & 9.6 \\
\hline 8 & Guinea & $0.353 / 88$ & $\mathrm{~T}$ & 35.2 & 29.7 & 24.7 & 9.7 & 5.8 & 3.9 \\
\hline 9 & Senegal & $0.352 / 22$ & $\mathrm{D}$ & 41.2 & 33.7 & 26.7 & 19.0 & 9.0 & 8.7 \\
\hline 10 & Senegal & $0.352 / 5$ & $\mathrm{~T}$ & 39.3 & 22.5 & 17.8 & 15.6 & 14.6 & 11.0 \\
\hline 11 & DxP & $0.418 / 571 \times 0.174 / 655$ & $\mathrm{~T}$ & 40.3 & 25.7 & 24.0 & 15.0 & 13.6 & 8.5 \\
\hline
\end{tabular}

Note: D - Dura, T - Tenera, P - Pisifera. Means within the same column with the same letter are not significantly different at $\mathrm{P} \leq 0.05$ from Tukey's Studentised Range (MSD) test. Figures in the row are minimum and maximum values. CV - coefficient of variations.

TABLE 4. GERMINATION RATE OF OIL PALM EMBRYOS DEHYDRATED USING SILICA GEL METHOD

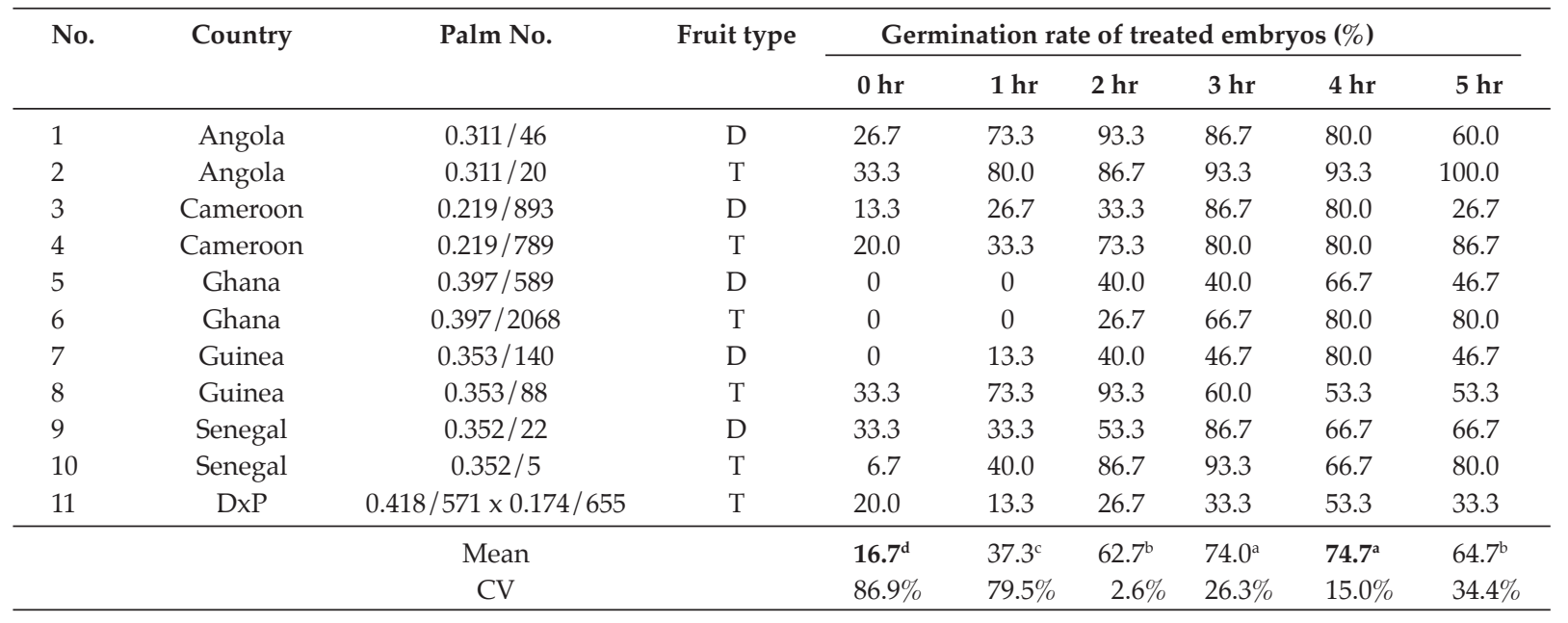

Note: D - Dura, T - Tenera, P - Pisifera. Means within the same column with the same letter are not significantly different at $\mathrm{P} \leq 0.05$ from Tukey's Studentised Range (MSD) test. Figures in the row are minimum and maximum values. CV - coefficient of variations. 
embryos increased with increasing desiccation periods from $13 \%$ without desiccation to nearly $90 \%$ after $4 \mathrm{hr}$ of dehydration (Engelmann et al., 1995). Lower germination rate was observed for embryos that have moisture content of $8.8 \%$ after $5 \mathrm{hr}$ desiccated on silica gel (Figure 1). This indicates that at moisture content of less than $10 \%$ the cryopreserved embryos have less ability to survive when cultured in vitro.

The treated embryos have higher viability than the untreated ones which indicates that removal of certain amount of moisture helps the embryos to remain viable during cryopreservation storage. This was already reported for oil palm embryos which have been dried to $10.4 \%$ moisture content (freshweight basis) showed no loss in viability during 8 months storage at $-196^{\circ} \mathrm{C}$ (Grout et al., 1983). It is also evident that dehydrating the embryos longer than $4 \mathrm{hr}$ caused in reduced rate of viability. Desiccation must be sufficient to ensure survival after freezing but not too intense to induce prolonged desiccation injury.

Ideal survival rates are generally achieved when samples are frozen with a water content of between $10 \%$ and $20 \%$ on fresh weight basis (Engelmann, 1992). The amount of moisture removed after $5 \mathrm{hr}$ of treatment was possibly too high that affect the ability for the embryos to survive after cryopreservation. Studies of recalcitrant seeds such as tea and jackfruit revealed that partially and fully matured embryonic axes could be desiccated to about $14 \%$ moisture content and successfully cryopreserved (Chandel et al., 1995). Similar successes in cryopreservation using zygotic embryos were reported in coffee (Pinto et al., 2016), rubber (Sam, 1996) and coconut (Sisunandar et al., 2010). Additional studies are required in order to simplify, standardise and develop cryopreservation techniques for oil palm germplasm collections.

\section{CONCLUSION}

It is apparent that moisture content affects embryo viability in oil palm. Among the three methods tested, silica gel method offers the shortest time to desiccate the embryos. Results showed that embryos had moisture contents below 20\% after $4 \mathrm{hr}$ silica gel treatment. Present study showed that moisture content of $10 \%-20 \%$ gave higher survival rate to cryopreserve oil palm embryos. The cryopreservation approach has potential to be applied to other type of oil palm samples such as pollen, kernels, somatic embryos which complements the long-term conservation of oil palm germplasm as alternative from the field genebank. Therefore, the next step is to apply cryopreservation to other type of oil palm samples besides embryos by using silica gel method and thus, the results can be compared.

\section{ACKNOWLEDGEMENT}

The authors would like to thank the Director-General of MPOB for permission to publish this article.

Moisture content and germination rate of embryos

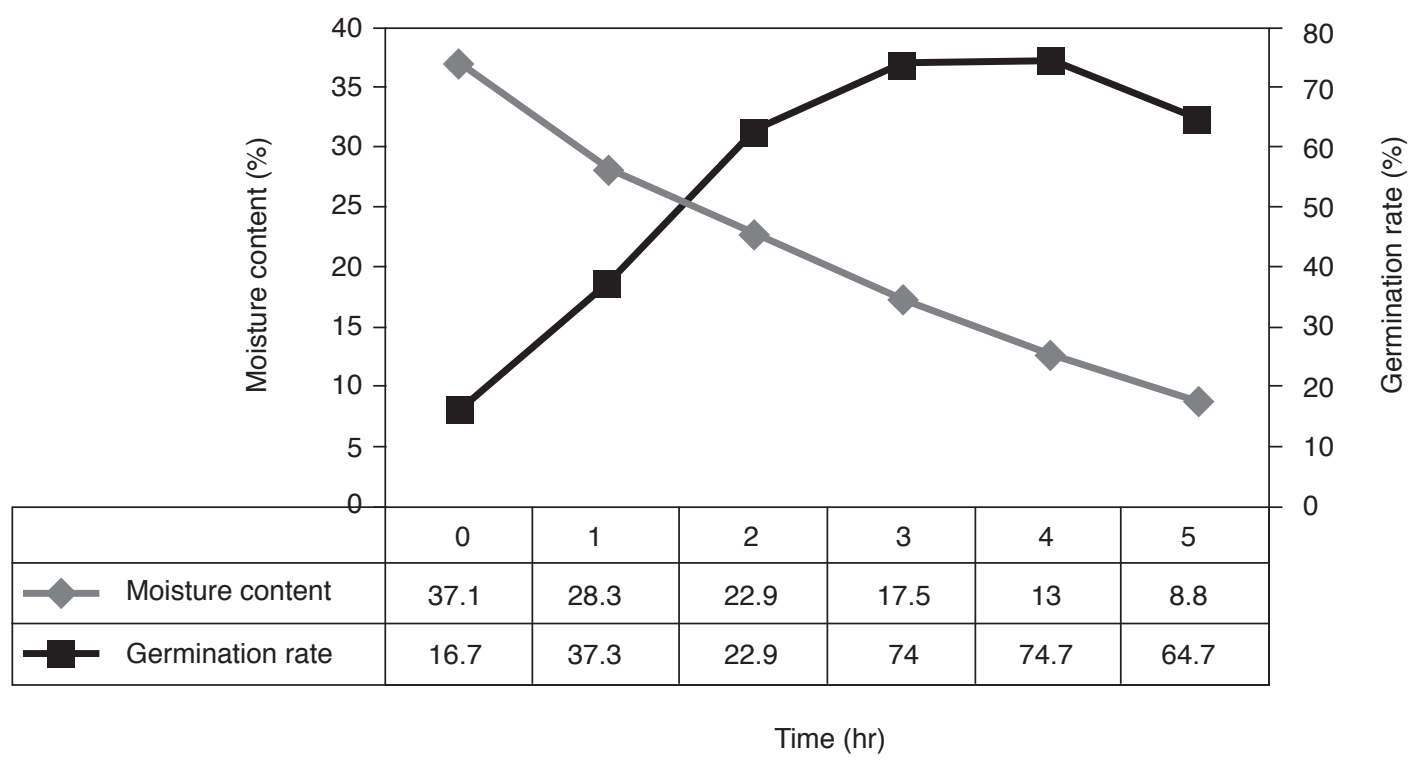

Figure 1. Moisture content reduction and germination rates of oil palm embryos from various germplasms using silica gel method (15 g, 5 hr). 


\section{REFERENCES}

BAJAJ, Y P S (1984). Introduction of growth in frozen embryos of coconut and ovules of citrus. Cryoletters, 23: 1215-1216.

CHANDEL, KPS;CHAUDHURY, R;RADHAMANI, $\mathrm{J}$ and MALIK, S K (1995). Desiccation and freezing sensitivity in recalcitrant seeds of tea, cocoa and jackfruit. Annals of Botany, 76: 443-450.

CHAUDHURY, R; RADHAMANI, J and CHANDEL, K P S (1991). Preliminary observation on the cryopreservation of desiccated embryonic axes of tea [Camellia sinensis (L.) O. Kuntze] seeds for genetic conservation. Cryoletters, 12: 31-36.

DUMET, D and BENSON, E E (2000). The use of physical and biochemical studies to elucidate and reduce cryopreservation-induced damage in hydrated/desiccated plant germplasm. Cryopreservation of Tropical Plant Germplasm (Engelmann, F and Takagi, H eds.). IPGRI, Italy.

ELLIS, R H; HONG, T D; ROBERT, E H and SOESTISNA, U (1991). Seed storage behavior in Elaeis guineensis. Seed Science Research, 1: 99-104.

ENGELMANN, F (1992). Cryopreservation of Embryos, Reproductive Biology and Plant Breeding (Dattee, C; Dumas, C and Gallais, A eds.). Springer-Verlag, Berlin. p. 281-290.

GOLMIRZAEI, A M and PANTA, A (2000). Advances in potato cryopreservation at CID. Cryopreservation of Tropical Plant Germplasm. Current Research Progress and Application (Engelmann, $\mathrm{F}$ and Takagi, $\mathrm{H}$ eds.). Japan International Research Centre for Agricultural Sciences, Tsukuba, Japan. p. 250-254.

GROUT, B W W; SHELTAN, K and PRICHARD, H W (1983). Orthodox behaviour of oil palm seed and cryopreservation of the excised embryos for genetic conservation. Ann. Bot., 52: 381-384.

HONG, T D; LININGTON, S H and ELLIS, R H (1998). Compendium of Information on Seed Storage Behaviour. RBG Kew. ISBN No. 1 90-034-7 490.

ISTA (1985). International rules for seed testing. Seed Science \& Technology, 13: 299-355.

MAKEEN, A M; NORMAH, M N; DUSSERT, S and CLYDE, M M (2005). Cryopreservation of whole seeds and excised embryogenic axes of Citrus suhuiensis cv. Limau langkat in accordance to their desiccation sensitivity. Cryoletters, 26: 259-268.

MALIK, S K; CHAUDHURY, R and PRITCHARD, H W (2012). Long-term, large-scale banking of citrus species embryos: comparisons between cryopreservation and other seed banking temperatures. Cryoletters, 33(6): 453-464.

MANDAL, B B; CHAUDHURY, R; ENGELMANN F; BHAG MAL; TAO, K L and DILLON, B S (2000). Proc. of the Regional Training Course on in vitro Conservation and Cryopreservation of Plant Germplasm. 12 - 25 October 2000, NBPGR, New Delhi, India. 283 pp.

NORMAH, M N; REED, B M and YU, Y L (1994). Seed storage and cryoexposure behaviour in hazelnut (Corylusavellana L. cv. Barcellona). Cryoletters, 15: 315-322.

PANIS, B; SWENNEN, $\mathrm{R}$ and ENGELMANN, $\mathrm{F}$ (2001). Cryopreservation of plant germplasm. Acta Hort., 650: 79-86.

PINTO, M S; PAIVA, R; SILVA, D P C; SANTOS, P A A; FREITAS, R T and SILVA, L C (2016). Cryopreservation of coffee zygotic embryos: dehydration and osmotic rehydration. Ciência $e$ Agrotecnologia, 40(4): 380-389.

RADHAMANI, J and CHANDEL, K P S (1992). Cryopreservation of embryonic axes of trifoliate orange [Poncirus trifoliate (L) Raf.]. Plant Cell Report, 11: 204-206.

RAJANAIDU, N (1994). PORIM Oil Palm Genebank: Collection, Evaluation, Utilization of Oil Palm Genetic Resources. PORIM, Bangi.

RAJANAIDU, $\mathrm{N}$ and JALANI, B S (1994) Oil palm genetic resources - collection, evaluation. Utilization and conservation. Presented at the PORIM Colloquium on Oil Palm Genetic Resources. PORIM, Bangi, 13 September 1994.

REED, B M (2001). Implementing cryogenic storage of clonally propagated plants. Cryoletter, 22: 97-104.

REED, B M; KOVALCHUK, I; KUSHNARENKO, S; MEIER-DINKEL, A; SCHOENWEISS, K; PLUTA, S; STRACZYNSKA, K and BENSON, E E (2004). Evaluation of critical points in technology transfer of cryopreservation protocols to international plant conservation laboratories. CryoLetters, 25: 341-352.

REINHOUD, P J; IREN, F V and KIJNE, J W (2000). Cryopreservation of undifferentiated plant cells. Cryopreservation of Tropical Plant Germplasm (Englemann, F and Takagi, H eds.). IPGRI, Italy.

SAM, Y Y (1999) Cryopreservation of Rubber (Hevea brasiliensis Muell. -Arg.) Zygotic Embryos Using Vitrification Technique. Master thesis. p. 84. 
SISUNANDAR, R A; TURQUAY, P; SAMOSIR, $Y$ and ADKINS, S W (2010). Cryopreservation of coconut (Cocos nucifera L.) zygotic embryos does not induce morphological, cytological or molecular changes in recovered seedlings. Planta, 232(2): 435447.
WILLIAMS, C N and HSU, Y C (1970). Oil Palm Cultivation in Malaya: Technical and Economic Aspects. Kuala Lumpur, Malaysia: University of Malaya Press. 